\title{
ESTABLISHMENT OF PUBLIC PROCUREMENT SYSTEM IN GEORGIA
}

\author{
Sulashvili Giorgi, Associate Professor of Georgian Technical University, Georgia \\ Nadiradze Gocha, PhD student of Georgian Technical University, Georgia
}

DOI: https://doi.org/10.31435/rsglobal_conf/25062021/7607

\begin{abstract}
The government procurement market is a macroeconomic system that includes interacting structural elements within a single system that are an integral part of a country's economic system. The state, as the owner of significant financial resources, acts as the largest subject of market relations in placing budget orders. State procurement (goods, construction works, services) is carried out to meet the most important state needs.

Modern market relations have confirmed the need to regulate the process of procurement of goods, services and construction works in country by the state, at the level of an independent institution of executive power/government. In the modern economy, public institutions face the need to regulate the flow of financial resources in order to make procurements for state and social needs, which spending entities must implement efficiently and effectively.
\end{abstract}

In this regard, certain areas of market research are discussed and some conclusions are presented.

Keywords: Spending entities, procurement, tender, financial resources.

Introduction. State Procurement directly affects the dynamics and structure of economy of the country. The state procures products that are essential for the functioning of health systems, education, law enforcement, the functioning of the military, the implementation of state programs, and so on.

Significant amounts of public expenditure on the purchase of products require the development of special procedures that enable the efficient use, accounting and control of public funds.

Basic text. Historical overview will help us to follow how the state procurement system was formed and developed in Georgia.

Public procurement reform in Georgia was launched with the support of the World Bank, IDF grant and SRS loan funds. Training seminars for state procurement specialists were organized, methodological materials were published and legislative normative documents were distributed.

The staff of the State Procurement Agency was trained in international training centers, international expert consultants in the field of procurement were hired to promote the institutional development of the Agency and to improve the legislative framework of procurement, and the office of the Agency was equipped with modern technical means. Permanental monitoring was provided from the World Bank missions over the institutional development of the newly established public procurement system in Georgia.

In December 1998, the Law of Georgia on State Procurement was adopted which entered into force in July 1999;

The statute on the Rule of Public Procurement was approved in August 1999, Georgia;

In 1999 the State Procurement Department was established in the Ministry of Economy of

In March 2001 changes were made to Law on Public Procurement, according to which the State Procurement Department was separated from the Ministry and reorganized into a legal entity under public law - the State Procurement Agency;

According to Decrees \# 223 and \# 224 of the President of Georgia, from June 5, 2001 "Regulations of the Agency and its Supervisory Board" were approved. The first members of the Supervisory Board and the Chairman of the Agency were appointed by the relevant decrees of the President of Georgia;

According to Order \# 1 of the Chairman of the Agency from October 15, 2001 statute "The Rule of Implementation of State Procurement" and its annexes were approved.

On January 1, 2002, pursuant to the Law of Georgia on "Amendments to the Code of Administrative Offenses of Georgia" were established the forms of administrative liability for noncompliance with the norms in force in the field of public procurement. 
According to the Law of Georgia on State Procurement, the State Procurement Agency is responsible for coordinating, monitoring and controlling public procurement activities throughout the country. The public procurement system in Georgia has become decentralized and the state procurement organization sunder took the authorization to implement it, amongst responsibility for the legality of the state procurement.

On April 20, 2005, new procurement legislation was adopted, which entered into force on January 1, 2006. The law changed the means of procurement, changed the rules for selecting the means of procurement, changed the rules of procurement planning, the need to request qualification data became entirely based on the content of the procurement based on the choice of the procuring entity. This law has undergone significant changes so far. The main change was the transition to the electronic platform of the public procurement system, which was carried out exclusively in electronic form. Since December 2010, significant changes have been made in the public procurement system, in particular, the so-called "Paper tenders" were canceled and e-procurement was introduced. The paperbased tender contained a high risk of corruption, as well as the risk of competition, high performance costs and a lack of transparency. There was also no flexible system taking into account the geographical factor, which means that the bidder was obliged to submit the tender documents (BID) in a sealed envelope to the office of the Procuring Entity -to the buyer's registered address. With the introduction of the e-procurement platform, Georgia's procurement system has become much more transparent and non-discriminatory, free and fair competition is protected as much as possible, and the risk of corruption is reduced.

In addition, those wishing to participate in the procurement can participate in the procurement and monitor it without leaving the office. Georgia is one of the few countries that have introduced a centralized and comprehensive e-procurement system. The system is innovative and largely meets EU (European Union) standards. Asit was mentioned above, public procurement is one of the most important components of the country's economy and public administration, and it is a priority for the Government of Georgia. Public procurement in Georgia in recent years accounts for about 10-11\% of GDP. In particular, the total cost of public procurement in 2017 amounted to 3,644,642,294 $\mathrm{GEL}^{1}$ The number of tenders announced in 2017 was 33,095. The total value of public procurement in 2018 amounted to 4,087,214,400 GEL, the number of tenders announced in 2018 was 32,597. The total volume of public procurement for the procurement of various services, goods and construction works during 2019 amounted to GEL $5,332,804,815$, which is about $11 \%{ }^{2}$ of the country's GD Pand accounted for $63 \%$ of the expenditure part of the state budget. The number of tenders announced during 2019 was 34216.

If the number of tenders with an estimated value of GEL 50,000 and more in 2018 was 7,736 this number in 2019increased to 8,246 . The change in the mentioned data is caused by the greater aggregation of the needs of the procuring organizations. According to 2019 data, the total estimated cost of relatively voluminous tenders has also increased. In particular, 94.1\% (4,801,948,205 GEL) from the total sum of approximate values of tenders announced in 2019 falls on those 8,246 tenders whose estimated values exceeded 50,000 GEL; In 2018, the similar figure was 92.7\%

In 2019,32,571 tenders were completed and respective final statuses were assigned to them in the se Procurement system. The contract were awarded with $71 \%$ of the completed tenders $(23,032$ tenders), while $29 \%$ of the tenders (9,539 tenders) in the system were assigned statuses "no bid received", "Contract not awarded" or "Cancelled".

The total estimated value of the tenders (23,032 tenders) in 2019 in which contracts were awarded was $3,963,988,455$ GEL, while total value of contracts was 3,609,891,394GEL ${ }^{3}$. Thus, savings obtained from the competition in the tenders amounted to 354,097,061GEL (approximately $9 \%$ of the total estimated value of tenders). Most of them, up to 262 million GEL, saving was in construction works procurement tenders.

Average number of bidders in the tenders completed in 2019 was 2.05. It should be noted that the highest average number of bidders was in construction works procurement tenders, and the lowest - in tenders announced for the purchase of various services.

Chart №1 shows Average number of bidders by procurement objects

\footnotetext{
${ }^{1}$ Annual report of state procurement Agency for 2017

${ }^{2}$ Annual report of state procurement Agency for 2018

${ }^{3}$ Annual report of state procurement Agency for 2019
} 


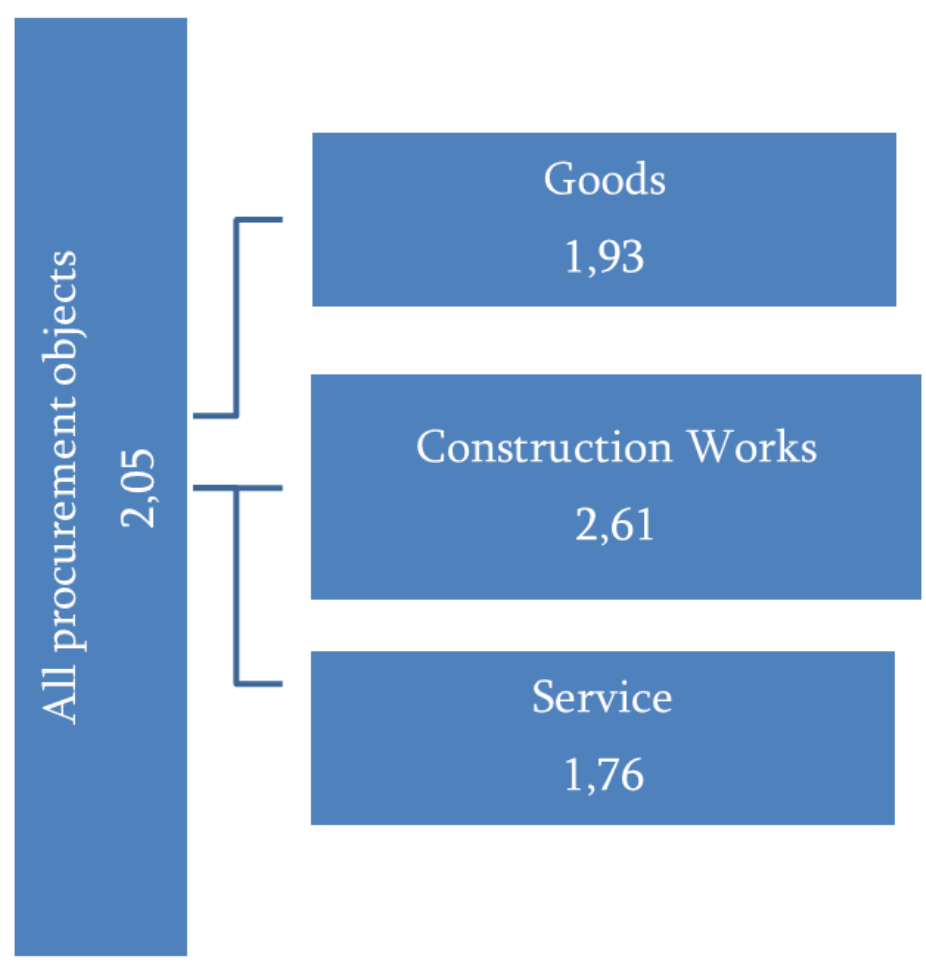

Chart №1. Average number of bidders by procurement objects

Conclusions. Increasing the efficient use and expenditure of public funds and financial resources in Georgia is an important issue for modern economic development, ensuring the balance and stable development of the national economy. The state acts as one of the main participant in the economic process, as a consumer of goods, construction works and services. Public procurement is an important element in the development of trade around the world and the efficient use of budget funds.

\section{REFERENCES}

1. Law of Georgia on State Procurement 20.04.05 №1388-I

2. Bulletin - 1 - State Procurement Agency 2002

3. Decree of the Government of Georgia on the Approval of the Association Agreement between Georgia and the European Union on Changes to be Made in the Field of Public Procurement, Guidelines for Fulfillment of Commitments under the Deep and Comprehensive Free Trade Agreement (DCFTA) №536, 31.03.16.

4. Annual report of the State Procurement Agency 2019

5. Annual report of the State Procurement Agency 2019

6. Brief 17, Public Procurement, e-Procurement. Support for Improvement in Governance and Management; August 2011

7. Towards Public Procurement Key Performance Indicators. Paulo Magina, Public Sector Integrity Division. 10th Public procurement Knowledge Exchange Platform. Istanbul, May 2014 